\title{
NUSHŪZ AS A CAUSE OF DOMESTIC VIOLENCE IN NIGERIA: THE QUR'ANIC PROVISION FOR PEACEFUL FAMILY LIFE AND THE ROLE OF MUSLIM WOMAN IN THE PROCESS
}

\author{
Hamza Abubakar Hussaini ${ }^{1}$ \\ Fatima Babayo $^{2}$
}

\begin{abstract}
One of the common social problems in Nigerian society nowadays is the increasing of violence against women and children, mostly by male members of a family. Unfortunately, the problem has assumed a new dimension in recent times as husbands become victims of their wives leading violence against them. Throughout the history of human existence on earth. The Qur'ān identifies nushüz as a factor that leads to family crises in marriage contracts and steps have been recommended for peaceful resolution of such disputes in the Qur'ān. However, in spite of this provision, violence against family members is on increase among Muslim families in Nigeria. Some of the questions that many will ask are whether Muslim couples are aware of the Qur'anic guidance in resolving family crises or not? To what extent do the Muslims follow the Islamic teachings in matters related to family life before, during and after disputes? How can such increasing
\end{abstract}

1 Department of Religious Studies, Faculty of Humanities, Management and Social Science, Federal University of Kashere, Gombe State, Nigeria, sgtu99@gmail. com

2 Department of Religious Studies, Faculty of Humanities, Management and Social Science, Federal University of Kashere, Gombe State, Nigeria, fatimababayo4@ gmail.com 


\begin{abstract}
violence be controlled following the teachings of the Qur'ān and Sunnah of the Prophet SAW? What shall be the role of Muslim women in promoting peaceful life within the family? The paper is an attempt to answer the above questions and recommend the best ways to improve family life among Muslims. This will be through analytical studies of relevant texts of the Qur'ān and Sunnah and the current realities in Nigerian Muslim families with a particular reference to Gombe metropolitan city of Gombe State, Nigeria. The paper recommends that Islamic values should be emphasized and upheld at all levels of family life by all and sundry.
\end{abstract}

Keywords: $n u s h \bar{u} z$, domestic violence, dispute resolution, husband, wife

\title{
INTRODUCTION
}

The importance of an attempt to examine the problems associated with family life and what often lead to physical violence among couples particularly, and family members can never be over emphasized. The scourge of domestic violence as well as other forms of violence against couples has eaten deep into the fabric of our society. Violence has taken different forms ranging from sexual to physical and psychological violence as well as other forms. Abusive partners and perpetrators base their actions on superior nature of the male sex, religion, law, custom, economic situation, family pressure, and their behavioral pattern. Although domestic violence can happen against either of the couples, in Nigeria, reports reveal "shockingly high" level of violence against women than male. ${ }^{3}$ Amnesty International reports that at least one third (and in some cases two-thirds) of women are believed to have been subjected to physical, sexual and psychological violence carried out primarily by husbands, partners and fathers while girls are often forced into unconsented marriage and are at risk of punishment if they attempt to escape from their husbands. More pathetic is the revelation of gross under reporting and non-documentation of domestic violence due to cultural factors. ${ }^{4}$

One of the causes of domestic violence in our society is disobedience committed by a wife to her husband. The defiance in Islam is termed "nushüz".

3 Ananymous, 'Half of Nigeria's Women Experience Domestic Violence,' AfrolNews http://www.afro.com/awrticles/16471, accessed on 10 November 2020.

4 Oyediran KA, Isiugo-Abanihe U., 'Perceptions of Nigerian Women on Domestic Violence: Evidence from 2003 Nigeria Demographic and Health Survey,' Afr J Reprod Health, vol. 9/2 (2005): 38-53. 
The term "nushüz" and the ways of tackling it is described in detail, including the steps that must be taken in tackling the nushizah, in the holy Qur'ān. Against this background, this paper seeks to discuss the Islamic perspective on domestic violence and ways of curbing the menace, specifically, with emphasis on "nushüz". To achieve this target, this paper has defined the concept of Violence as well as "nushüz". It further elaborates the Islamic objective of establishing family on love, mercy and harmony. Thirdly, it discusses the Qur'anic concept of "nushūz". Additionally, it mentions rights and duties of couples. And finally, as fifth and sixth, it discusses the Nigerian and Gombe state perspective on domestic violence.

\section{CONCEPT OF VIOLENCE}

Violence can be seen as a use of physical force to harm someone or damage property. Mariam Webster Dictionary defines violence "as the use of physical force so as to injure by distortion, infringement or profanation". ${ }^{5}$ Another writer defines violence as "the intentional use of physical force or power threatened or actual against a group of community that either result in a high likelihood of resulting in injury, death, psychological harm or deprivation". ${ }^{6}$ It has surfaced from the above definitions that violence is a behavior by persons against one another or property with the intention to threaten or cause physical injury.

It is difficult to determine the extent of domestic violence in Nigeria, because official records on violence are not collected in the country. It is said that domestic violence affects women of all communities. It involves women of all ethnic and religious groups living in both rural and urban areas. Unfortunately, there is under reporting of spousal abuse (is very common) particularly in polygamous family which is widely practiced in Nigeria. It is common in polygamous families in Nigeria to see husband discriminating one of his wives and left the other (s). Additionally, Female domestic servants are also vulnerable to violence at home by their masters or other family members. The escalation of domestic violence is worrisome and it requires concerted efforts to address it.

\footnotetext{
5 Mariam webster Dictionary.

6 Alison Rutherford, Anthony B. Zwi, Natalie J. Grove \& Alexander Butchart J., 'Violence: A Glossary,' Epidemiol Community Health, vol. 61 (2007): 676-680.
} 


\section{ISLAMIC FOUNDATION OF A FAMILY}

The Qur'ān and Prophetic practices clearly illustrate the nature of relationship between spouses. The Qur'ān states that the relationship should be that of tranquility, love, tenderness, protection, encouragement, peace, kindness, comfort, justice and mercy. The Qur'ān states:

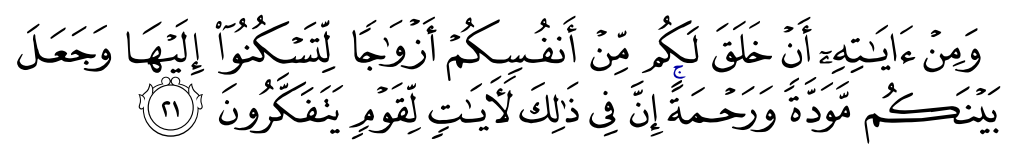

"And among His Signs is, that He created for you wives from among yourselves, that you may find repose in them, and He has put between your affection and mercy. Verily, in that are indeed signs for a people who reflect."

(Surah al-Rūm, 30: 21)

He created for you mates from among yourselves. Domestic violence and abusive behavior towards women are forbidden because they contradict the objectives of Islamic jurisprudence and the Qur'ān injunctions of righteous and kind treatment on women. It was addressed under the concept of harm in Islamic law which includes a husband's failure to provide obligatory financial support "nafaqa" for his wife, a long absence of the husband in ability to fulfil his wife's sexual needs or any maltreatment of the wife's family members.

A wife is entitled to "nafaqa" (feeding, accommodation, shelter and all their components) from her husband as far as Islamic Sharia guidelines are concerned. The only time she forfeits this right is, when she is guilty of "nushüz". Any violence and coercion against women that is used to control or subjugate her is considered oppressive and unacceptable in Islam even if it's upheld by cultural practices. Domestic violence and oppression against women remain a major concern in today's society. The problem is severe because it is affecting people in any angle of life regardless of socio-economic status, ethnicity, age or religion. It exists in both Muslim and non-Muslim societies. The position of Islam on the kind treatment of women is very clear as mentioned in the Qur'ān and exemplified through the life and character of the Prophet SAW. According to the prophetic traditions a hadith was reported from ' $\bar{A}$ 'ishah RA which says;

$$
\begin{aligned}
& \text { عن عائشة ، قالت :قال رسول الله (صلى الله عليه وسلم): خيركم }
\end{aligned}
$$

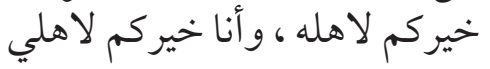


"On the authority of 'A' ishah RA: that the Messenger of Allah said: The best of you is the best to his wives, and I am the best of you to my wives." 7

A husband is expected to treat his wife kindly which can reflect as a Muslim's good character and in turn as a reflection of his faith. The Prophet SAW exemplified how one should not hurt his wife emotionally or physically, remove anything that will harm her, treat her kindly and be patient with her. He should communicate effectively with her and involve her in decision making and support her in times of difficulty. Allah SWT instructs men to be kind to their wives and treat them well to the best of their ability. A devout Muslim should always remember that pleasing his wife is part of faith that earns him the pleasure of Allah SWT. This is contrary to the general misconception upheld by many of the Nigerian husbands that relegated the status of wives to that of a mere domestic servant who does not have anything to contribute in decision making on home issues. Evidently, the Prophet used to consult his wives on different issues including the matters that affect administration of the Ummah. In fact, men were commanded to consult their wives on certain issues that affect the family. Allah SWT says:

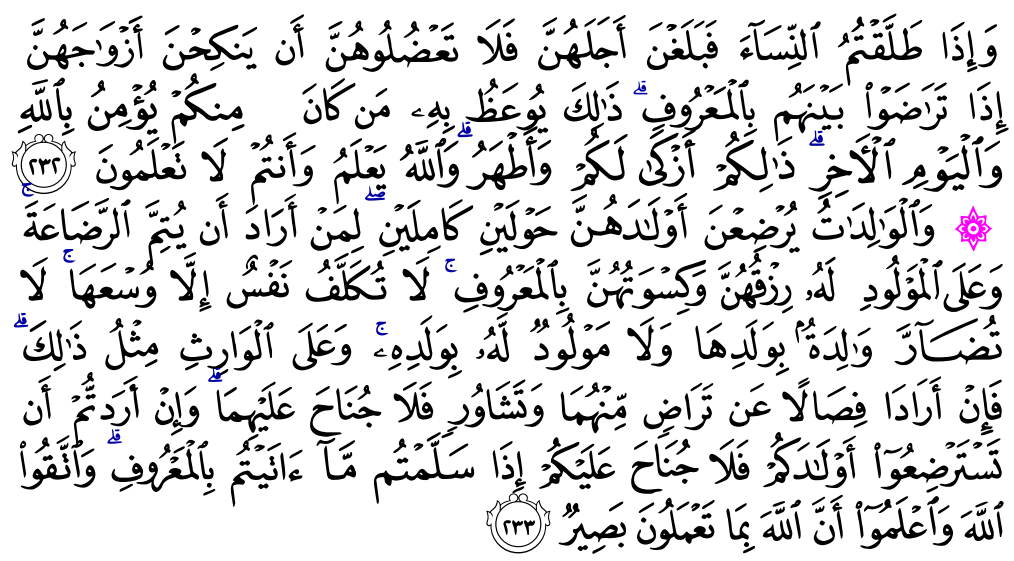

"And when you have divorced women and they have fulfilled the term of their prescribed period, do not prevent them from marrying their (former) husbands, if they mutually agree on reasonable basis. This (instruction) is an admonition for him among you who believes in Allah and the Last Day. That is more virtuous

Al-Tirmidhī, Abū 'Īsā Muhammad Ibn 'Īsā Ibn Sawrah Ibn Mūsā, Sunan alTirmidhī, vol. 5 (Bayrūt: Dār Iḥyā’ al-Turāth al-'Arab̄i, n.d.), 50, "Bāb Faụl Azwāj al-Nabī," hadīth no. 3895. 
and purer for you. Allah knows and you know not. The mothers shall give suck to their children for two whole years, (that is) for those (parents) who desire to complete the term of suckling, but the father of the child shall bear the cost of the mother's food and clothing on reasonable basis. No person shall have a burden laid on him greater than he can bear. No mother shall be treated unfairly on account of her child, nor father on account of his child. And on the (father's) heir is incumbent the like of that (which was incumbent on the father). If they both decide on weaning, by mutual consent, and after due consultation, there is no sin on them. And if you decide on a foster suckling-mother for your children, there is no sin on you, provided you pay (the mother) what you agreed (to give her) on reasonable basis. And fear Allah and know that Allah is All-Seer of what you do."

(Surah al-Baqarah, 2: $232 \&$ 233)

Mutual consultation between the husband and the wife has serious effects in controlling domestic conflicts as it is evidently clear from the above verses.

\section{NUSHŪZ: THE QUR'ANIC CONCEPT OF FAMILY DISPUTE}

"Nushüz" is viewed fi in Islam as one of the causes of family disintegration in human society, broken homes and consequently affecting the society as a whole. It was reported by Ibn 'Abbas, āal-Suddiy and Mujahid, that "nushūz" involves any act of disobedience or insincerity from the wife in relation to her husband. ${ }^{8}$ However, as far as the Qur' $\bar{a} n$ is concerned, nushüz is not a monopoly of wives, it can occur from either the husband or the wife. In whichever case, the Qur' $\bar{a} n$ has given detailed procedure on the ways of reconciliation in such family disputes. Allah SWT says:

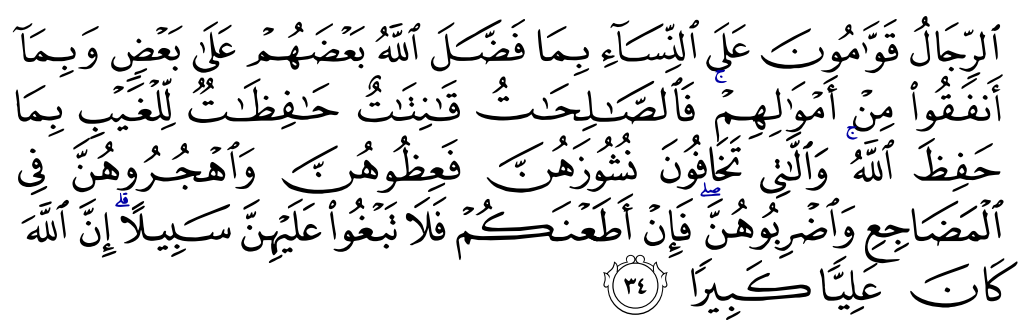

8 Al-Jassas, Aḥmad Ibn 'Alī Abū Bakr, Aḥkām al-Qur'ān, vol. 2 (Bayrūt: Dār Iḥyā', al-Turāth al-'Arabī, 1405AH), 231. 
"Men are in charge of women by (right of) what Allah has given one over the other, and what they spend for maintenance from their wealth. Therefore, the righteous women are devoutly obedient and guard the husband's absence of what Allah would have them guard. As those women on whose part are fear disloyalty and ill conduct, admonish them (first), next refuse to share their beds and last beat them lightly, but if they returned to obedience, seek not against them means (of annoyance) for Allah is most high, great above you all."

(Surah al-Nisā', 4: 34)

In the above verse, the Almighty Has provided three different steps for addressing "nushüz", these are, admonishing, boycotting and finally, beating. For the better understanding it will be a welcome development if we discuss these methods more extensively.

Firstly, "admonish them". The husband as the head of the family was privileged to carry out certain correctional measures within the limits of the Shariah in order to correct his erring wife. He should first counsel her, boycott her when the counseling fails. The worse situation is to punish her with beating, if the situation warrants that, even though it was highly discouraged by the Prophet SAW, beating a wife is only resorted to, if advice and ignoring her in the bed do not produce the desired results. Furthermore, severe beating is not recommended. Muslim recorded that Jabir said that during the Farewell Hajj, the Prophet SAW said;

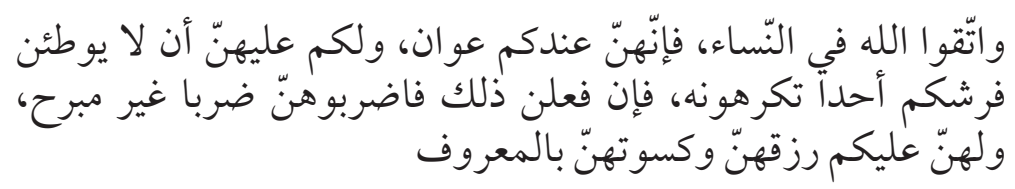

"Fear Allah regarding women, for they are your assistants. You have the right on them that they do not allow any person whom you dislike to step on your mats. However, if they do that, you are allowed to beat them lightly. They have a right on you that make available test their provision and clothes, in a reasonable manner." 9

9 Muslim, Abī al-Ḥusayn Muslim Ibn al-Hajjāj Ibn al-Qushayrī al-Naysabūrī, Șaḥịh Muslim (Bayrūt: Dār al-Jiyl, n.d.), "Kitāb 16, Bāb Ḥajj al-Nabī," hadīth no. 3009. 
Mufti Shafi ${ }^{10}$ opines that "Beating has been permitted as a forced option in ولن a particular mode. Right alone with this option to men, it appears in hadith يضرب خياركم which means that 'good men among you will never beat women". Thus, such action is nowhere reported from the Prophets of Allah SWT "On the final note, both the husband and the wife can seek redress from the higher authorities to the situation persists after all the above procedures had been followed.

Disagreement and misunderstanding are inevitable in human life as human beings are bound to disagree. In family life, the disagreements mostly occur as a result of the weak nature of the women folk and the husbands are obliged, as part of the responsibilities of qawwamah, to bear with their wives and tolerate the short-comings that are inherent in them. One of such hadith says;

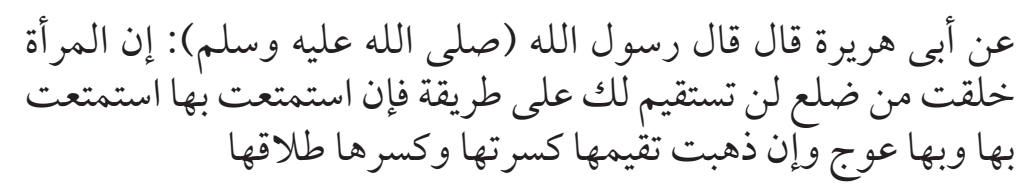

"In the narration of Muslim, Abū Hurayrah said: The Messenger of Allah said: Woman has been created from a rib and will in no way be straightened for you: so, if you want to benefit from her, you will benefit from her while crookedness remains in her. If you attempt to straighten her, you will break her, and breaking her is divorcing her." 11

It could be observed from the above hadith that one should be patient with his wife. This is because losing patience leads to divorce, which is highly discouraged in Sharia. The husbands were also mandated to be kind, fair and just in dealing with their wives and that qualifies a man to be among the best of the of the Prophet's Ummah "The best of you is he who is the best to his family". For sustainable family relation, parents were commanded by the Prophet to consider moral values and religious background in choosing a life partner for to their children when it comes to marriage. This is one of the measures Islam takes to ensure a decent family.

Other measures include encouragement of reconciliation between the family and the community. The ultimate solution to family disputes and violence against any member in case of the husband's failure to bring his wife to order

10 Mawlana Muftī Shāfi', Ma 'rīf al-Qur'ān, vol. 2 (Karashi: Dār al-'Ulūm, 1995), 423.

11 Muslim, Abī al-Ḥusayn Muslim Ibn al-Hajjāj Ibn al-Qushayrī al-Naysabūrī, Saḥīh Muslim, "Kitāb 18, Bāb al-Wașiyyah bi al-Nisā'," hadìth no. 3719. 
is to refer the case to reconciliation panel. "Sulh" is encouraged in the Qur' $\bar{a} n$ to resolve any inter-human disputes. The concept of "sulh" is emphasized in Qur'än as a means of ensuring peaceful coexistence among the family and community members. Allah SWT declares that "and making peace (sulh) is better" instead of adherence to greed of human nature. Passages of the Qur' $\bar{a} n$ that discuss sulh making peace include:

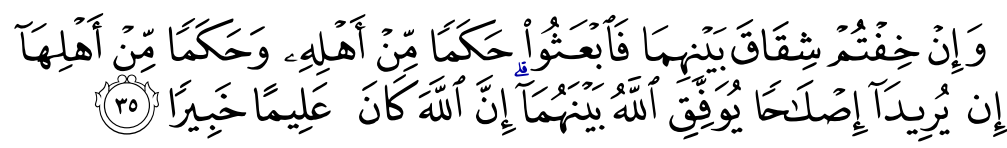

"If you fear a breach between the two, appoint (two) arbitrators, one from his family and the other from hers, if they both wish for peace, Allah will cause their reconciliation. Indeed, Allah is Ever All-Knower, Well-Acquainted with all things."

(Surah al-Nisā', 4: 35)

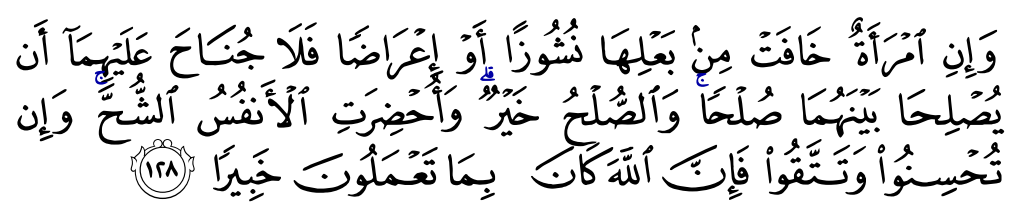

"And if a woman fears cruelty or desertion on her husband's part, there is no sin on them both if they make terms of peace between themselves; and making peace is better. And human souls are swayed by greed. But if you do good and have taqwa, verily, Allah is Ever Well-Acquainted with what you do."

(Surah al-Nisā', 4: 128)

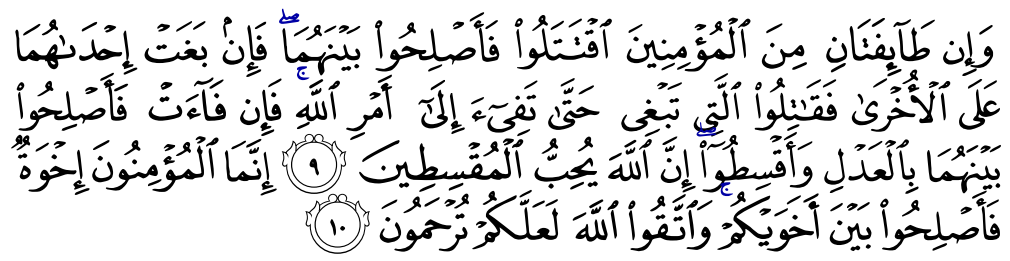

"And if two parties among the believers fall to fighting, then make peace between them both. But if one of them outrages against the other, then fight you (all) against the one that which outrages till it complies with the command of Allah. Then if it complies, then make reconciliation between them justly, and be equitable. Verily, Allah loves those who are the equitable. The believers are but a 
brotherhood. So make reconciliation between your brothers, and have taqwa of Allah that you may receive mercy."

(Surah al-Hujurāt, 4: 9-10)

There were certain cases of family conflict in the days of the Prophet SAW within his household and in the houses of his companions. Sometimes it occurred as a result of misunderstanding among the couples and negative perception against the partner. The causes of the disputes always determined the complication in resolution mechanism that was employed by the Prophet in coming up with solution. Sometimes one of the parties had to sacrifice his certain rights or privileges for peaceful and mutual coexistence to be achieved, Saudah Bint Zam 'ah, the wife of the Prophet SAW made a good example. In this regard she sacrificed her nights to ' $\bar{A}$ 'ishah, her co-partner. ${ }^{12}$ It was also incumbent upon all parties and their guardians to verify any information regarding disagreements and conflict so as not to take decision based on a false allegation.

The Prophet SAW demonstrated a good example in handling allegation case against his wife, ' $\bar{A}$ ' ishah when she was alleged to have committed zina. Her mother, Ummu Roman was also a good example on the role of Muslim women in handling domestic complications. She comforted her daughter and encouraged her to remain calm and steadfast in the period of trial. One of the alarming family disputes during the time of the Prophet SAW was the case of Thabit Ibn Qays and his wife and Sa'ad ibn al-Rabi' who slapped his wife. Nigerian Muslim families have a lot to learn from these cases as means of controlling domestic violence against any family member. It is imperative to declare that even during the time of the Prophet SAW and the Companions, family disputes and misunderstanding existed but did not result in high rate of violence like the ones we witness today among Muslim families in Nigeria.

\section{THE PROPHET'S APPROACH IN RESOLVING FAMILY DISPUTE}

Conflict in marriage is inevitable but, both men and women should understand that women are just like a garment to men and vice-vasa, Allah SWT says:

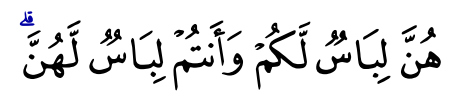

"They are your garments and you are their garments."

12 Abū Dāwud, Sulayman Ibn al-Ash'ath al-Sijistān̄̄ al-'Azdī, Sunan Abū Dāwud (Bayrūt: Dār Iḥyā’ al-Turāth al-'Arabī, n.d.), "Kitab 12, Bāb fì al-Qasm Bayn alNisā'," hadìth no. 2137. 
(Surah al-Baqarah, 2: 187)

There was a time when one of the Prophet's wife Sawdah realized that the Prophet SAW had only married her out of sympathy. She knew this fact clearly when the prophet kindly separated from her to release her of such critical position. Thus, she preferred the Prophet desire and granted her night to 'A' ishah RA and Allah SWT sent a revelation on that. 'A' ishah used to spend her night and Sawdah's night while the Prophet SAW kept Sawdah as his wife after she offered to forfeit her day to 'A' 'ishah with the consent of the Prophet SAW if one is patient with the wife he dislikes and treat her as other wives are treated, then Allah SWT knows what one does and will definitely reward for it perfectly. Qur'ān says:

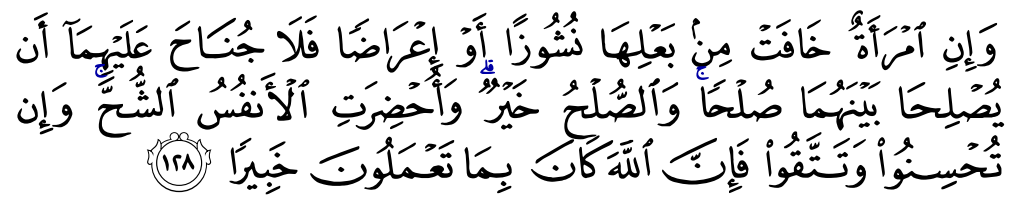

"And if a woman fears cruelty or desertion on her husband's part, there is no sin on them both if they make terms of peace between themselves; and making peace is better. And human inner-selves are swayed by greed. But if you do good and keep away from evil, verily, Allah is Ever Well Acquainted with what you do."

(Surah al-Nisā̄', 4: 128)

However, the apparent wording of the verse refers to the situation where the wife forfeits some of her rights on her husband with the husband agreeing to this concession and that this settlement is better than divorce, and there was no blame on them if they arrange on amicable settlement between themselves. Therefore, 'A 'ishah RA used to spend Sawdah's night with the Prophet SAW.

Furthermore, reconciliation is what Allah SWT loves most and women are in the right position to play a vital role in reconciliation process. Allah SWT says:

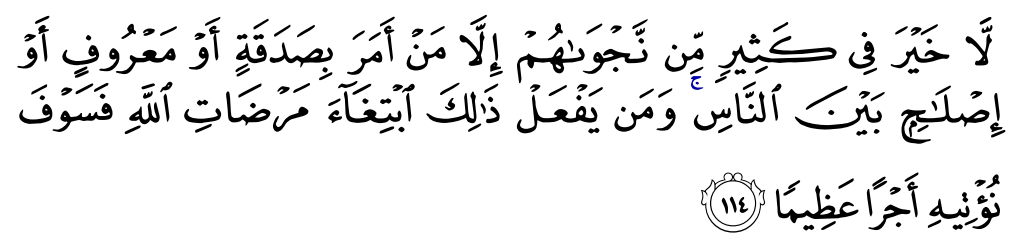

"There is no good in most of their secret talks save (in) him who orders șadaqah (charity) in Allah's Cause, or ma'rüf Islamic 
Monotheism and all the good and righteous deeds which Allah has ordained), or conciliation between mankind, and he who does this, seeking the Pleasure of Allah, we shall give him a great reward."

(Surah al-Nisā', 4: 114)

Based on this, in reconciliation one can understand that a leader can intervene for the benefit his followers paying much attention on the issue from both parties is one of the major act in resolving family disputes. There are a lot of incidence that happen during the time of the Prophet among are his companions. For instance, the case of Zaid Ibn Thabit and his wife Zainab. Reported to have intervene in Surah al-Ahzab, Allah SWT tells us about the incidence of bint Jahash:

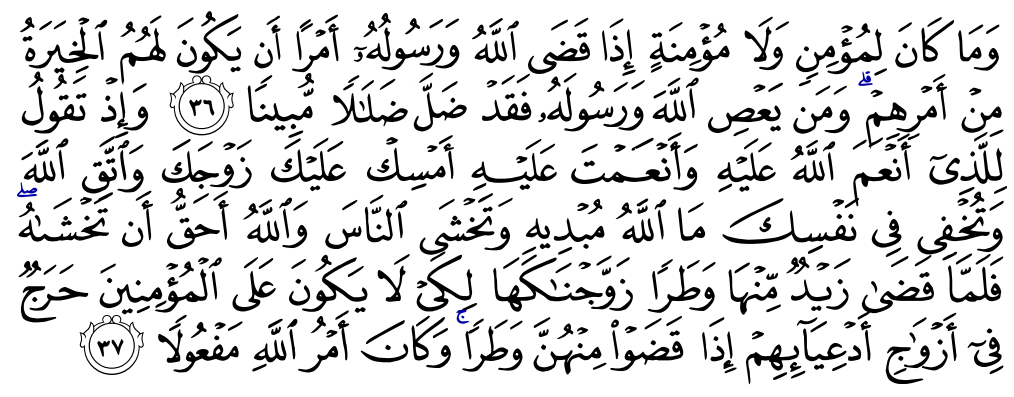

"It is not for a believer, man or woman, when Allah and His Messenger have decreed a matter that they should have any option in their decision. And whoever disobeys Allah and His Messenger, he has indeed strayed in a plain error. And (remember) when you said to him (Zaid bin Hârith $R A$ the freedslave of the Prophet $S A W$ ) on whom Allah has bestowed Grace (by guiding him to Islâm) and you (O Muhammad SAW too) have done favour (by manumitting him) "Keep your wife to yourself, and fear Allah." But you did hide in yourself (i.e. what Allah has already made known to you that He will give her to you in marriage) that which Allah will make manifest, you did fear the people (i.e., Muhammad SAW married the divorced wife of his manumitted slave) whereas Allah had a better right that you should fear Him. So when Zaid had accomplished his desire from her (i.e. divorced her), We gave her to you in marriage, so that (in future) there may be no difficulty to the believers in respect of (the marriage of) the wives of their adopted sons when the latter have no desire to keep 
them (i.e. they have divorced them). And Allah's Command must be fulfilled."

(Surah al-Aḥzāb, 33: 36 \& 37)

So, it can be safely deduced from this verse that Prophet SAW has intervened in the matter between these two of his companions to be sure that a better family life was established. Though, both Zainab and Zaid RA loved the Prophet SAW and they are good people in their own way, the marriage has to be ended finally. Another instance is the case of Barirah an ex-female slave with her former husband who was still a slave at the time she was set free.

Above all, the Prophet SAW himself employed dialogue as a means of resolving disputes within his family. In short, the Prophet SAW made a general statement thus;

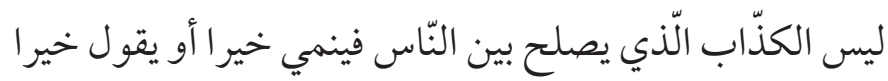

"Who makes peace between the people by inventing good information or saying good things is not a liar." 13

In another chapter Allah SWT disclose the dispute that happen among the wives of the Prophet SAW that is Hafsah Bint Umar and ' $\bar{A}$ ' ishah RA in which Allah SWT says:

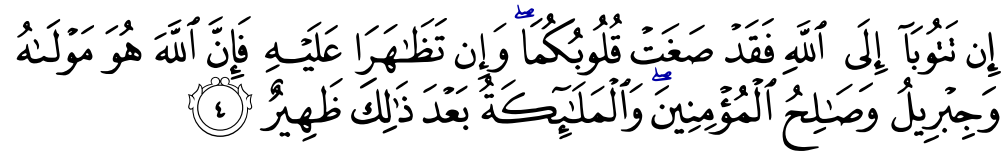

"If you two turn in repentance to Allah, (it will be better for you), your hearts are indeed so inclined (to oppose what the Prophet SAW likes), but if you help one another against him Muhammad( SAW, then verily, Allah is his Maula (Lord, or Master, or Protector, etc.), and Jibrael (Gabriel), and the righteous among the believers, and furthermore, the angels are his helpers."

(Surah al-Tahrīm, 66: 4)

Hafsah realized the gravity of what she had done to her noble husband when she disclosed the Prophet's secret, but after the Prophet forgave her, she lived in tranquility and repose again.

13 Al-Bukhārī, Abī 'Abd Allāh Muhammad Ibn Ismā‘il al-Ju'fî, al-Jāmi ‘ al-Ṣah̄ịh, Kitab 57, Bab "Laysa al-Kadhib, hadīth no. 2546. 


\section{NUSHŪZ AS UNDERSTOOD BY MUSLIMS IN NIGERIA}

There is a high level of misunderstanding and misapplication of the teachings of the Qur'ān and Sunnah in matrimonial life among many couples. For example, this wide misunderstanding in the Muslim individuals manifest while commenting on the verses of the Qur'ān without a proper substantial understanding of their context. ${ }^{14}$ For instance, one of the common misunderstanding is that many people misinterpret the following verse.

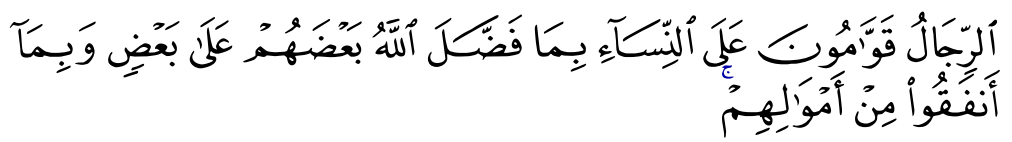

"Men are the protectors and maintainers of women, because Allah has made one of them to excel the other, and because they spend (to support them) from their means."

(Surah al-Nisā', 4: 34)

As a result of the physical power they have, over women and therefore, they can do whatever they wish to their wives without any limit. Unfortunately, they couldn't reason with the immediate preceding phrase after "al-rijāl qawwāmūna 'ala al-nisā'. For the purpose of clarity, it will be recommended to embark on a voyage of discovery to fully comprehend the meaning of the verse. Allah SWT says, "Bima faddaLallah" meaning men excel over women and are better than them as a result of certain responsibilities and qualities. One of such responsibilities is stated in the verse where Allah SWT says: "wabima anfaqu min amwālihim" Meaning, the dowry expenditures and various expenses that are ordained for men to spend on women and become their maintainers. Other tasks that are ordained for them are provision of feeding, shelter, healthcare, clothing, education on religious and mundane matters, good training and all that is required for decent life. ${ }^{15}$

Ibn Kathīr also elucidates on the meaning of the verses as he clearly explains the meaning of each segment of the verse and deduces that; Men are the protectors and maintainers of women implies that man is responsible for the woman, and he is her maintainer, caretaker and leader who disciplines her when she deviates. To discipline her here does not mean that he should beat

14 Sambo, Abubakar, 'The Practice of Polygamy Among Muslims in Gombe Metropolis: Problems and Solution,' (Masters Dissertation, Department of Islamic Studies and Shariah, Bayero University, Kano, Nigeria, 2018).

15 Ibn Kathīr, Abū Fidā’ Ismā'il Ibn 'Umar, al-Qurshī al-Damashq̄î, Tafsīr al-Qur'ān al-'Aż̄im, vol. 1 (Qāhirah: Dār al-Taybah, 1999), 610. 
or flog her with a cane that can cause her serious injury because the Prophet SAW warns men not to beat their wives even though it is permissible. It has been transmitted in Sunan of Abū Dāwud thus:

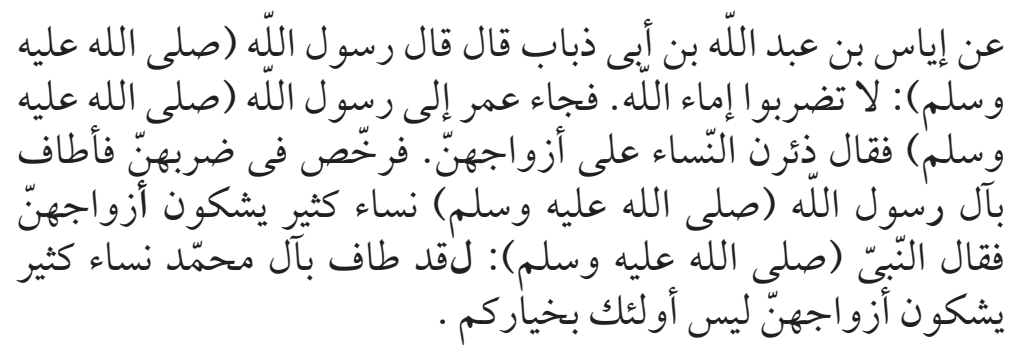

"Iyas ibn 'Abd Allāh ibn Abū Dhubab reported the Messenger of Allah as saying: "Do not beat Allah's, female slave" but when Umar came to the Messenger of Allah and said : "Women have become emboldened towards their husbands, " he (the Prophet) gave permission to beat them. Then many women came round the family of the Messenger of Allah complaining against their husbands. So, the Messenger of Allah said: "Many women have gone round Muhammad's family complaining against their husbands. They are not the best among you." 16

In order to build a model society, Islam provides systematic division of labor and responsibilities in family administrative matters so as to guide the affairs of the believers and every member of a family has his own role and responsibility to discharge for the progress and development of family and the community at large in order to ensure peace and order in the Muslims' family life. Allah SWT declares in the Qur' $\bar{a} n$ that men are protectors and maintainers of women ( qawwāmūn) the word "qawwāmūn" signifies persons who take the responsibility of safe guarding the interest of another. This position comes to men as opposed to women, not only because they have more physical strength and greater capacity for hard work, but also because it is extremely important that in every family there should be a head that may give orders and settle things among the family members. It should be born in mind that both the husband and the wife should exercise their obligations in accordance with God consciousness (taqwa) and based on the set principles of guiding family relations for the purpose of clarification.

Therefore, for marital institution to be properly guided based on Islamic teachings and principles as contained in the Qur' $\bar{a} n$ and authentic Sunnah of

16 Abū Dāwud, Sulayman Ibn al-Ash'ath al-Sijistānī al- 'Azdī, Sunan Abū Dāwud, 12, "Bāb Darb al-Nisā'," hadīth no. 2148. 
the Prophet SAW, the spouses need to be taught the rights and responsibilities of husbands and wives in Islam. It is unfortunate that many couples are not well educated on this aspect and most of their engagements in marital life were based on the traditional practices and the prevalent customs.

\section{DUTIES AND RESPONSIBILITIES OF THE SPOUSES}

Both the husbands and wives have certain dos and don'ts in conjugal relation in Islam, some are shared responsibilities among both, while others were exclusively for husband or wife. These sets of responsibilities were meant to regulate and guide the family life for better. On a general note both the husband and the wife are obligated to do everything possible to their marital bondage. Both are ordained to treat each other with ( $m a{ }^{\prime} r u \bar{f}$ ) which entails general kindness, mercy, respect, and humility. The following are some of the specific roles of the husbands towards their wives:

a) Understand the importance of marrying and choosing a good wife who is likely to be an excellent mother and caregiver to children.

i) To show respect towards wife, esteem her and do not undervalue or be insensitive towards her

ii) To be kind and gentle towards wife; do not be harsh, overly critical of her, or unpleasant in behavior or manner.

b) Do not belittle or undervalue wife's advice, for the Prophet SAW, himself used to consult his wives

c) Deal with wife's anger or jealousy with wisdom and patience

d) Shower love, care and attention on her

e) If one is in a polygamous marriage, treat all the wives equally and do not withhold affection from one wife and bestow it excessively on another.

The following are some of the specific roles of the wives towards their husbands;

a) Choose a good husband

b) A wife is expected to give a husband the respect that his is due for it, obey him and take care of him

c) Treat husband's parents and family with kindness and respect

d) Be eager to please a husband and endear self to him 
e) Do not disclose husband's secrets

f) Support husband and offer him advice

g) Help husband to obey Allah SWT the Almighty and do good deeds

h) Fill husband's heart with happiness and joy

i) Beautifying self for a husband is necessary

j) Be cheerful when meeting a husband

k) Share joys and sorrows of a husband

1) Do not look at men other than a husband

m) Do not describe other women to a spouse partner

n) Create an atmosphere of peace and tranquility for a husband

o) Be tolerant of a partner and forgive his faults

p) Develop a strong, assertive character and deal with situations wisely

q) Encourage husband to spend for the sake of Allah SWT

The following Qur'anic verse gives a definite responsibility to both husband and wife and requires mutual cooperation between them for blissful marital life. Allah SWT says in Qur'ān:

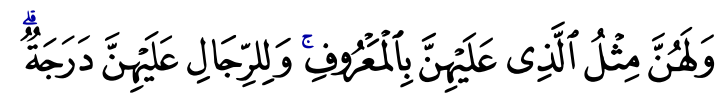

"And they (women) have rights (over their husbands as regards living expenses, etc.) similar (to those of their husbands) over them (as regards obedience and respect, etc.) to what is reasonable, but men have a degree (of responsibility) over them."

(Surah al-Baqarah, 2: 228)

\section{ANALYZING THE FAMILY DISPUTES IN GOMBE}

Gombe is situated in the center of north eastern part of Nigeria which comprises of eleven local governments. The state is bounded with three state that are closer to the border. Borno to the east Adamawa to the south and Yobe to the North. And the common language spoke in the state is Hausa and Fulfulde. Closed examination and analysis on most of the reported cases of domestic violence and family crises that occur in Gombe metropolis show that the nature and causes of such violence are not much different to what is obtainable in other 
parts of northern Nigerian communities. It is evident from the investigations carried out by the researchers that there is absence of the Islamic guidance on family life as exemplified by the Prophet and his Companions in the life-style of most of the families. This is due to lack of adequate knowledge or refusal to put the knowledge into practice. It's observed that there is improvement in the level of Islamic scholarship in terms of the number of schools and students' participation. However, the content of the curriculum and emphasis on practical application of the knowledge are some of the challenges that need to be looked into with a view to providing genuine solutions to our socio-economic and religious crises that have bedeviled our societies. Many of the couples that have reported cases of misunderstanding and/or violence are good in reading the texts of the Qur' 'an and other religious books. But unfortunately, they are, to some extent, handicapped in practical application of the knowledge that are contained in the texts they learn. ${ }^{17}$

The process of initiating and contracting marital relation is also believed to be responsible our some of the frequent disputes among families. This is because, there were higher expectations from many couples during courtship which remain a mirage after the marriage. Many of the prospective husbands and wives pretend to be what they are not and possess what they do not have in order to attract their partners before marriage. In some other cases, some prospective couples engage themselves in dirty activities before marriage and such engagements turn to mutual suspicion after marriage. This leads to certain $n u s h \bar{u} z$ activities from either of the couple against the other and all the processes employed to resolve the problem cannot address the issue. This is because the suspicion remains in their hearts. It is also a problem that many of prospective partners do not pay attention to religious and moral background of their partners before marriage. Material affluence and social status play more determining roles in the choice of husband or wife, as against moral and religious qualities that were emphasized by the Prophet SAW.

Some of the parents are also guilty in compounding the problems, by blindly supporting their wards whether rightly or wrongly. We have a good lesson to learn from the stance of Ummu Rooman, the wife of Abū Bakr RA and mother of ' $\bar{A}$ 'ishah, the wife of the prophet in the case of blasphemous allegation against her daughter. Parents should train their wards in the best Islamic manner and guide them on the best way to behave even in the trial moment. They should restrain their wards from doing anything that is capable of undermining the wellbeing of the family life.

17 Sambo, Abubakar, 'The Practice of Polygamy Among Muslims in Gombe Metropolis: Problems and Solution,' 25. 
As the research goes on, it found out that family dispute is inevitable and most of the violence that are happening domicile are caused by family misunderstanding and many parents are not using the concept of nushüz in Qur'ān 4V:128 in resolving issues. For instance, when things happen the Qur'ān shows that both of the couple can bring their parents or guardians to sit down and resolve whatever the case might be. But in most cases, couples do not give their parents or guardians a chance to know what is the real problem and sometimes, the mechanism they use does not help matters. The researchers interview few couples on how their issues were resolved and find out that parents don't call the two parties at the same time. They discuss with them separately and no matter how right is the wife and how concrete is her reason the parents will overpower her with whatever the husband fabricates and tells them which can give him a chance of creating another problem between the spouses.

In most cases couples don't appreciate what they have, a man cannot stand on his own and avoid unnecessary conflict by providing the necessary care for his wife while a woman limits her patience to endure the challenges of conjugal relation. In a relationship there is no perfect husband or wife most of the couples don't apply this in their marital affairs. When a man is not satisfied with some acts of his wife he will start planning to marry another one and if it's woman she will start thinking going back to her parent's house or feeling like changing another partner. All these are the simple issues that spouses have to avoid violence on women in the society. From the parent side, when spouses are hot and in high temper, reconciliation cannot take place. For instance, if the husband tells his wife to leave, some parents may return her back immediately without a thorough investigation.

\section{CONCLUSION}

The researchers, in the previous pages, have examined the concept of nushüz in the Qur 'a $\bar{n}$ and its effects on marriage contracts. It also examines few cases of nushüz during the time of the Prophet SAW like that of Thabit Ibn Qays and his wife, Sa'ad ibn al-Rabi'ah and his wife the daughter of Muhammad ibn Maslamah as well as new approach by Saudah Bint Zam`ah, the wife Prophet SAW in settling matrimonial issues. The research sheds light on the Islamic approach in resolving family crises and the importance of obeying the Prophetic footsteps in handling similar situation in our time. The researchers conclude that the escalation of domestic violence against family members, particularly women as a result of poor Islamic education and disregard to the Shariah provisions on family life. Based on this, it is recommended that 
each and every member of the family should have adequate knowledge of the Shariah on family and other matters and put the knowledge into practice. The paper finally observes as follows;

a) The superior position given to men in respect to women is not only on physical strength but also in the ability to settle issues among the family members amicably.

b) Each and every family member has certain roles to play for the progress and development of the family and the Muslim community.

c) Women can play a vital role in resolving family dispute and avoiding violence in some marital houses, if they are properly trained on Islamic family life.

d) Both husband and wife should carry out their responsibilities with diligence and taqwa (piety).

\section{REFERENCES}

Abū Dāwud, Sulayman Ibn al-Ash'ath al-Sijistānī al-'Azdī, Sunan Abū Dāwud (Bayrūt: Dār Ihyā̄’ al-Turāth al-'Arabī, n.d.).

Alison Rutherford, Anthony B. Zwi, Natalie J. Grove \& Alexander Butchart J., 'Violence: A Glossary,' Epidemiol Community Health, vol. 61 (2007): 676-680.

Ananymous, 'Half of Nigeria's Women Experience Domestic Violence,' AfrolNews http://www.afro.com/awrticles/16471, accessed on 10 November 2020.

Al-Bukhārī, Abī 'Abd Allāh Muḥammad Ibn Ismā'il al-Ju'fī, al-Jāmi' alSaḥịh (Bayrūt: Dār Ibn Kathīr, 1987).

Ibn Kathīr, Abū Fidā' Ismā'il Ibn 'Umar, al-Qurshī al-Damashqī, Tafsīr alQur'ān al- 'Ażīm, vol. 1 (Qāhirah: Dār al-Taybah, 1999).

Al-Jassas, Aḥmad Ibn 'Alī Abū Bakr, Ahkām al-Qur'ān, vol. 2 (Bayrūt: Dār Ihỵā' al-Turāth al-'Arabī, 1405AH).

Mawlana Muftī Shāfi', Ma 'rīf al-Qur'ān, vol. 2 (Karashi: Dār al-'Ulūm, 1995).

Muslim, Abī al-Husayn Muslim Ibn al-Hajjāj Ibn al-Qushayrī al-Naysabūrī, Șahịh Muslim (Bayrūt: Dār al-Jiyl, n.d.).

Oyediran KA, Isiugo-Abanihe U., 'Perceptions of Nigerian Women on Domestic Violence: Evidence from 2003 Nigeria Demographic and Health Survey,' Afr J Reprod Health, vol. 9/2 (2005): 38-53. 
Sambo, Abubakar, 'The Practice of Polygamy Among Muslims in Gombe Metropolis: Problems and Solution,' (Masters Dissertation, Department of Islamic Studies and Shariah, Bayero University, Kano, Nigeria, 2018).

Al-Tirmidh̄̄, Abū 'Īsā Muḥammad Ibn 'Īsā Ibn Sawrah Ibn Mūsā, Sunan alTirmidhī, vol. 5 (Bayrūt: Dār Iḥyā’ al-Turāth al-'Arabī, n.d.). 
Jurnal Syariah, Jil. 29, Bil. 1 (2021) 43-64 